\title{
Hemiplegic (unilateral) cerebral palsy in northern Stockholm: clinical assessment, brain imaging, EEG, epilepsy and aetiologic background factors
}

\author{
Elsa Tillberg ${ }^{1 *}$ (D) Bengt Isberg ${ }^{2}$ and Jonas K. E. Persson ${ }^{3}$
}

\begin{abstract}
Background: The purpose of this study was to describe clinical presentation, epilepsy, EEG, extent and site of the underlying cerebral lesion with special reference towards aetiologic background factors in a population-based group of children with hemiplegic cerebral palsy.

Methods: Forty-seven children of school- age, fulfilling the SPCE (Surveillance of Cerebral palsy in Europe)-criteria of hemiplegic cerebral palsy, identified via the Swedish cerebral palsy register, were invited and asked to participate in the study.

Results: Fifteen boys and six girls participated. Of the sixteen children born at term, five had no risk factors for cerebral palsy. Two out of five preterm children presented additional risk factors. Debut of motor impairment was observed in the first year of life in sixteen children. Age at diagnosis varied from 2 months to 6 years. Epilepsy was common and associated with grey- and white matter injury.

Conclusions: Recognizing the importance of risk factors for cerebral palsy, any child with these risk factors should be offered a check-up by a paediatrician or a paediatric neurologist. Thereby reducing diagnostic delay. Epilepsy is common in hemiplegic cerebral palsy and associated with grey-and white matter injury in this cohort.
\end{abstract}

Keywords: Hemiplegic cerebral palsy, Aetiologic background, EEG, Epilepsy, Brain imaging

\section{Background}

In a previous study of a subgroup of hemiplegic cerebral palsy, we found a high frequency of epilepsy, almost 50\% [1]. We therefore wanted to study a population-based group of hemiplegic cerebral palsy in both term and preterm children.

Cerebral palsy (CP) is an umbrella term for motor impairments, that share features of a non-progressive brain injury, acquired during the early stages of its development [2-4] .These motor impairments can have different aetiologic backgrounds, occurring in the antenatal, perinatal or postnatal period [2-4]. The motor impairment is

\footnotetext{
* Correspondence: elsa.tillberg@ki.se

'Department of Clinical Neuroscience, Karolinska Institute, Tomtebodavägen 18 A, 17177 Stockholm, Sweden

Full list of author information is available at the end of the article
}

often associated with visual- and hearing deficits as well as epilepsy and cognitive impairment $[2,3,5]$.

Epilepsy is common in cerebral palsy, present in 30 $40 \%$ of cases [4, 6, 7]. Zelnik found seizures in $35,5 \%$ of children, in the subgroup hemiplegia.

Epilepsy is related to the underlying brain lesion [6] . In term children with cerebral palsy, grey matter lesions are more common [6].

The occurrence of neonatal seizures is a risk factor for cerebral palsy [8-10]. Neonatal seizures can be a strong predictor for epilepsy in cerebral palsy $[7,11,12]$. Neurodevelopmental outcome however, is predominantly due to the underlying brain lesion. But clinical studies suggest that the seizures themselves may be detrimental to the developing brain [9].

(c) The Author(s). 2020 Open Access This article is distributed under the terms of the Creative Commons Attribution 4.0 International License (http://creativecommons.org/licenses/by/4.0/), which permits unrestricted use, distribution, and reproduction in any medium, provided you give appropriate credit to the original author(s) and the source, provide a link to the Creative Commons license, and indicate if changes were made. The Creative Commons Public Domain Dedication waiver (http://creativecommons.org/publicdomain/zero/1.0/) applies to the data made available in this article, unless otherwise stated. 
Few studies address specific EEG-patterns and semiology in cerebral palsy [13]. Most studies of epilepsy in cerebral palsy are based on medical records, or information from cerebral palsy registers. A few direct clinical studies were found $[11,12,14]$. In the studies of Singhi and Gururaj a complete clinical examination was performed on 105, respectively 56 children with epilepsy and cerebral palsy $[12,14]$.

The cerebral lesion can be classified according to the anatomical site of the brain lesion: Cerebral cortex, pyramidal tract, extrapyramidal systems or cerebellum [3]. The extent of the underlying cerebral lesion must also be recognized $[3,15]$. The imaging patterns according to type, as classified by Reid, includes white matter injury, grey matter injury, focal vascular insults and malformations [15].

Children with cerebral palsy, epilepsy and cognitive disability constitute a large patient group in paediatric neurology. An increasing number of register-based studies, address these impairments simultaneously $[6,16,17]$.

Due to the heterogeneity of cerebral palsy, it could be useful to study a subgroup, such as hemiplegic cerebral palsy $[1,5,18]$. We wanted to study both clinial presentation, EEG and brain abnormalities found in each child.

\section{Aetiologic background factors}

Since Fiona Stanley published her important book "Cerebral Palsies: Epidemiology and causal pathways", there is consensus that cerebral palsy results from multiple factors acting along a causal pathway $[4,5]$.

Socioeconomic factors are important [19], especially parents educational level [20-22].

Gestation: "Paradox: Very strong relationship between prematurity and risk of cerebral palsy versus the fact that most patients with cerebral palsy are born at term" [4]. Children born before 28 weeks' gestation, and all preterm children with additional risk factors, such as intracranial haemorraghe, encephalitis, meningitis, seizures and other conditions leading to care in the neonatal unit, are included in the Swedish neonatal society's high risk group. These children are offered a follow up at the neonatal clinic according to the Guidelines from Swedish neonatal society 2015 [23]. Children born at 28-32 weeks are considered an intermediary risk group. For term infants, low birthweight, especially infants being small for gestational age (SGA), is a significant risk factor $[10,16]$.

Infection: Cerebral palsy has long been associated with congenital cytomegalovirus (CMV) infection [4]. More recent reports have been published, where CMVDNA was assessed by PCR in the neonatal screening card [24]. In a study from 2017, $31(9,6 \%)$ of 401 children with cerebral palsy, tested positive for CMV- DNA.

\section{Research approach}

The purpose of this direct, not register-based, study was to outline clinical presentation, epilepsy, EEG and brain imaging in a population-based group of children with hemiplegic cerebral palsy. The site and extent of the underlying cerebral lesion was also documented. All case records and case histories were reviewed with special reference towards aetiologic background factors. The focus of the study was to identify aetiologic backgrounds- and risk factors, to enable early identification and better care for these children.

\section{Methods \\ Definitions}

Cerebral palsy was defined as: Motor impairments, due to a non-progressive brain injury, during the early stages of its development $[2,3]$. Hemiplegic cerebral palsy was defined as a unilateral motor impairment.

Classification. Participants were classified according to the Surveillance of Cerebral Palsy in Europe (SPCE) guidelines [18]. SPCE encompasses fourteen European centers for the study of cerebral palsy, in eight European countries. The guidelines are used to measure the functional loss associated with cerebral palsy and define criteria for each subtype of cerebral palsy, by distribution and type of motor impairment: Hemiplegic (unilateral) or bilateral, spastic, dyskinetic or ataxic. The timing of the supposed cerebral insult is divided into three categories: pre-, peri- or postnatal.

\section{Case identification}

Children aged seven to 16 years, fulfilling the SPCEcriteria of hemiplegic cerebral palsy, were identified via the Swedish national cerebral palsy register (CPUP). A written survey asking for these children, was also sent to all local rehabilitation-units in northern Stockholm. These children were invited and asked to participate in the study. The caregivers of twenty-one children gave written and informed consent for the children's participation, and the study was approved by the regional ethics committee.

\section{Clinical assessment}

All case records were reviewed with particular attention to pathogenic factors and pre-peri- or postnatal risk factors for cerebral palsy (18). Common perinatal risk factors are neonatal seizures, asphyxia and cerebral infection. Postnatal head trauma or surgery are important postnatal risk factors. Prenatal risk factors were defined as described by McIntyre [11]. The results of visual- and audition testing were collected. All of the children were examined by the same paediatric neurologist (ET). Parents' occupation was documented.

Case history included information about gestation, birth-weight, perinatal events, developmental milestones, 


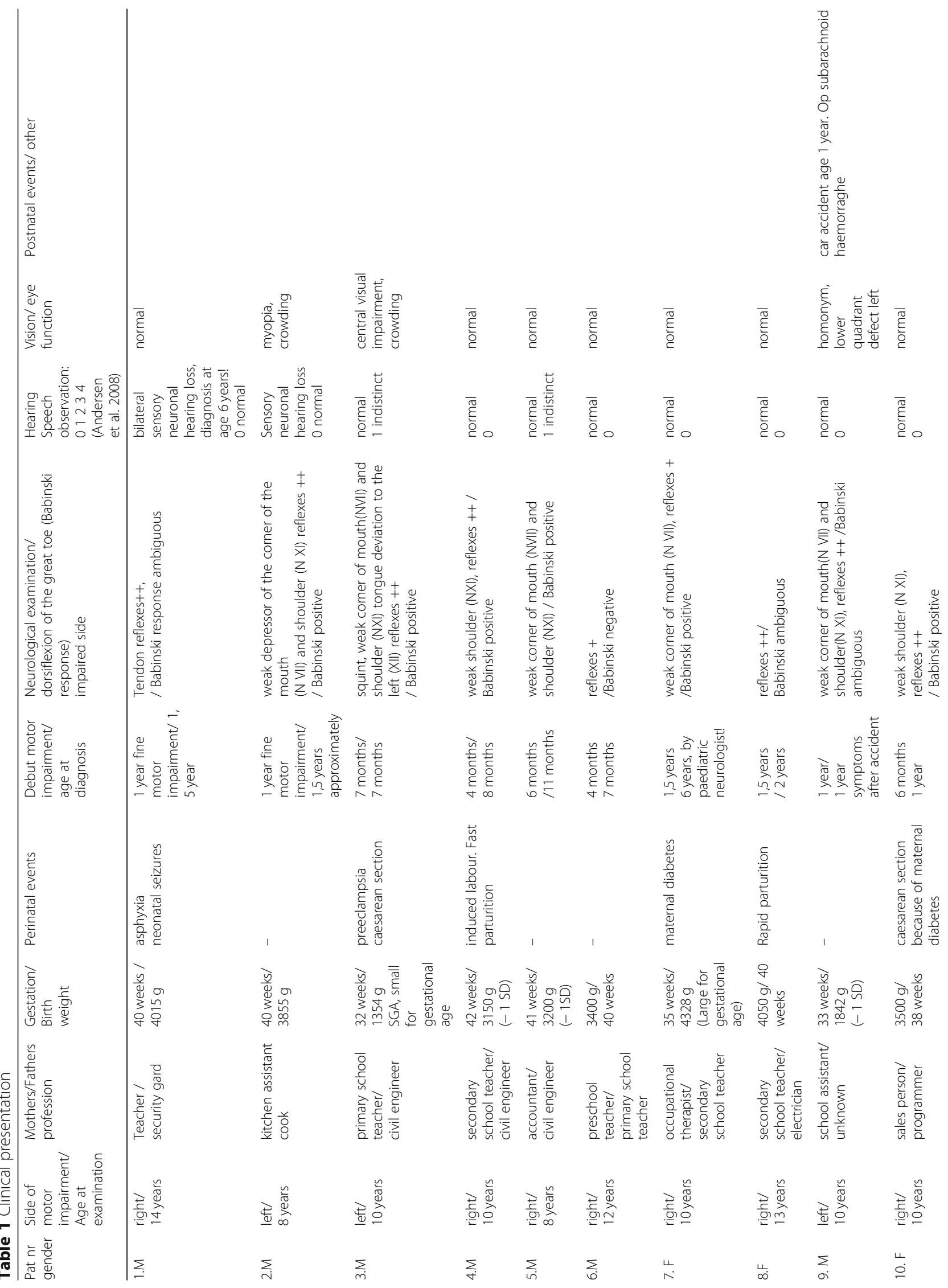




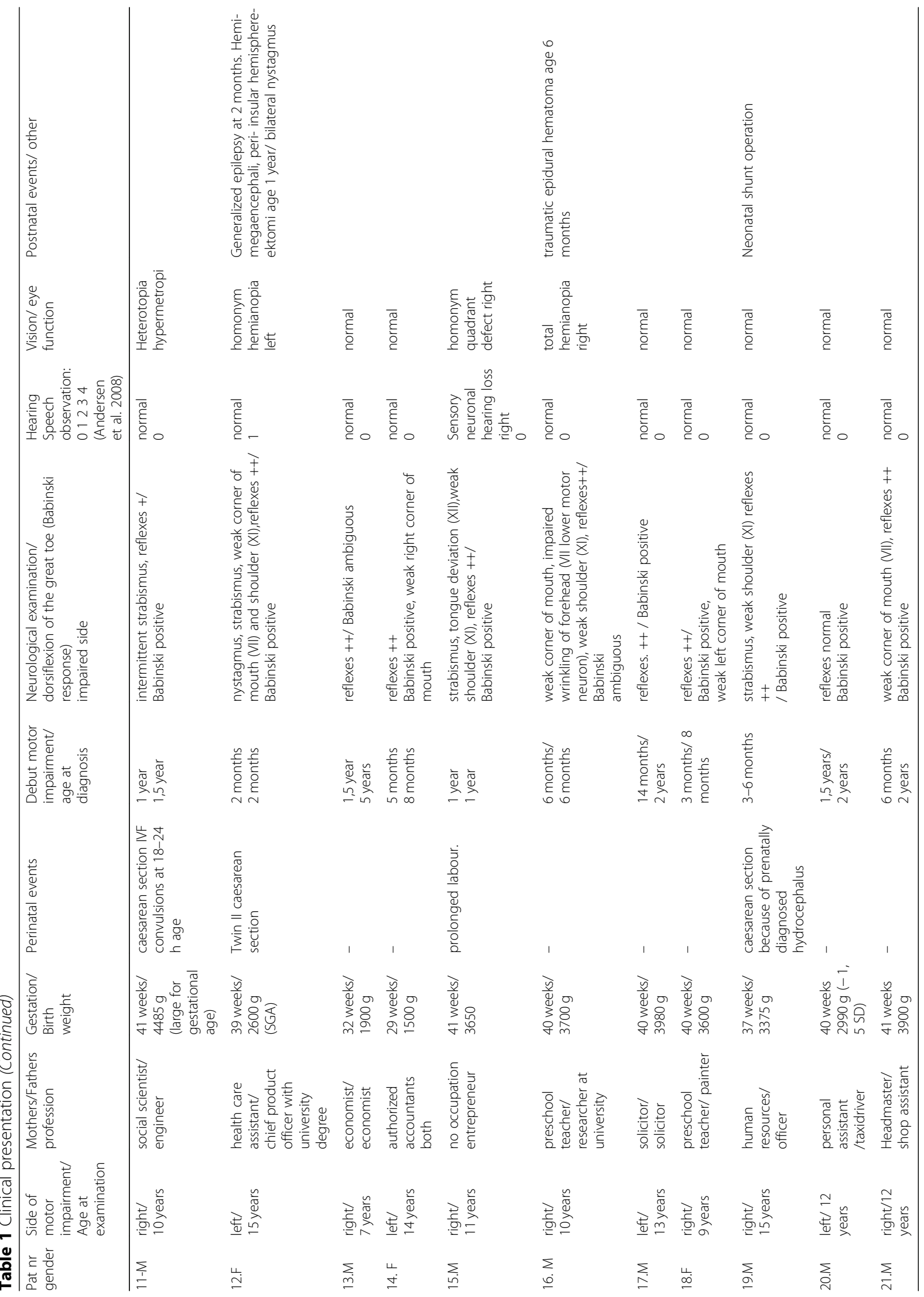


Table 2 Brain imaging findings

\begin{tabular}{|c|c|c|c|c|c|c|c|c|c|c|}
\hline \multirow{2}{*}{$\begin{array}{l}\text { Child } \\
\text { No\# Gender }\end{array}$} & \multirow{2}{*}{$\begin{array}{l}\text { MRT/ } \\
\mathrm{CT}\end{array}$} & \multirow{2}{*}{$\begin{array}{l}\text { Clinical } \\
\text { side }\end{array}$} & \multirow{2}{*}{$\begin{array}{l}\text { Gestation } \\
<34 \\
\text { weeks }\end{array}$} & \multirow{2}{*}{$\begin{array}{l}\text { Gestation } \\
>=34 \\
\text { weeks }\end{array}$} & \multicolumn{4}{|c|}{ Imaging pattern } & \multirow[t]{2}{*}{ Miscellaneous } & \multirow{2}{*}{$\begin{array}{l}\text { Localisation } \\
\text { Extent and details of } \\
\text { brain lesion }\end{array}$} \\
\hline & & & & & Malformation & $\begin{array}{l}\text { White } \\
\text { matter } \\
\text { injury }\end{array}$ & $\begin{array}{l}\text { Grey } \\
\text { matter } \\
\text { injury }\end{array}$ & $\begin{array}{l}\text { Focal vascular } \\
\text { insult }\end{array}$ & & \\
\hline 1.m & MRT & Right & & + & & + & + & & $\begin{array}{l}\text { Affection of left } \\
\text { pyramid tract, basal } \\
\text { ganglia, cerebellum }\end{array}$ & $\begin{array}{l}\text { Left } \\
\text { Volume loss in white } \\
\text { matter and cortex }\end{array}$ \\
\hline $2 . m$ & MRT & Left & & + & + & & & & & $\begin{array}{l}\text { Right } \\
\text { Polymicrogyri whole } \\
\text { hemisphere }\end{array}$ \\
\hline 3.m & MRT & Left & + & & & + & & & & $\begin{array}{l}\text { Bilateral } \\
\text { PVL (periventricular } \\
\text { leukomalacia) } \\
\text { ill defined }\end{array}$ \\
\hline 4.m & $\begin{array}{l}\text { MRT/ } \\
\mathrm{CT}\end{array}$ & Right & & + & & & & $\begin{array}{l}\text { Infarction of } \\
\text { a.cerebri } \\
\text { media, almost } \\
\text { total }\end{array}$ & & $\begin{array}{l}\text { Left } \\
\text { Extensive loss of } \\
\text { parenchyma in frontal } \\
\text { and parietal lobe }\end{array}$ \\
\hline 5.m & CT & Right & & + & & + & & & & $\begin{array}{l}\text { Bilateral, but } \\
\text { predominantly left } \\
\text { PVL }\end{array}$ \\
\hline $6 . \mathrm{m}$ & - & Right & & & & & & & & No examination \\
\hline $7 . f$ & MRT & Right & & + & & + & & & & $\begin{array}{l}\text { Bilateral } \\
\text { Slight PVL }\end{array}$ \\
\hline $8 . f$ & MRT & Right & & + & & + & & & & $\begin{array}{l}\text { Left, } \\
\text { Slight PVL }\end{array}$ \\
\hline $9 . m$ & CT & Left & + & & & + & + & & $\begin{array}{l}\text { Traffic accident at } \\
\text { age } 1 \text { year }\end{array}$ & $\begin{array}{l}\text { Right } \\
\text { Volume loss } \\
\text { frontotemporally } 43 \times 46 \\
\mathrm{~mm}\end{array}$ \\
\hline $10 . f$ & MRT & Right & & + & & & & $\begin{array}{l}\text { Infarction of a } \\
\text { cerebri media }\end{array}$ & $\begin{array}{l}\text { Wallerian } \\
\text { degeneration }\end{array}$ & $\begin{array}{l}\text { Left } \\
\text { Extensive }\end{array}$ \\
\hline 11.m & CT & Right & & + & & & & $\begin{array}{l}\text { Infarction } \\
\text { a.cerebri } \\
\text { ant+posterior }\end{array}$ & & $\begin{array}{l}\text { Left } \\
\text { Extensive }\end{array}$ \\
\hline $12 . f$ & MRT & Left & & + & + & & & & $\begin{array}{l}\text { Hemi } \\
\text { megaencephali }\end{array}$ & $\begin{array}{l}\text { Right } \\
\text { Extensive } \\
\text { Peri-insular hemisphere } \\
\text { ectomi at age } 1 \text { year }\end{array}$ \\
\hline 13.m & CT & Right & + & & & + & + & & & $\begin{array}{l}\text { Left } \\
\text { Thin spalt extends from } \\
\text { lateral cerebral surface } \\
\text { medially }\end{array}$ \\
\hline $14 . f$ & CT & Left & + & & & + & & & & $\begin{array}{l}\text { Right } \\
\text { Moderate PVL }\end{array}$ \\
\hline $15 . m$ & $\begin{array}{l}\text { MRT/ } \\
\mathrm{CT}\end{array}$ & Right & & + & & + & + & & $\begin{array}{l}\text { Pyramidal tract loss } \\
\text { Affection of radiatio } \\
\text { optica }\end{array}$ & $\begin{array}{l}\text { Left } \\
\text { Extensive parenchymal } \\
\text { defect frontal-parietal + } \\
\text { temporal lobe }\end{array}$ \\
\hline $16 . m$ & $\begin{array}{l}\text { MRT/ } \\
\text { CT }\end{array}$ & Right & & + & & & & $\begin{array}{l}\text { Post traumatic } \\
\text { epidural } \\
\text { hematoma }\end{array}$ & & $\begin{array}{l}\text { Left } \\
\text { Extensive loss of most of } \\
\text { hemisphere+ small } \\
\text { lesion in cerebellar lobe } \\
\text { Post traumatic epidural } \\
\text { hematoma at age } 6 \\
\text { months }\end{array}$ \\
\hline 17.m & MRT & Left & & + & & + & & & & $\begin{array}{l}\text { Right } \\
\text { PVL superior of lateral } \\
\text { ventricle }\end{array}$ \\
\hline
\end{tabular}


Table 2 Brain imaging findings (Continued)

\begin{tabular}{|c|c|c|c|c|c|c|c|c|c|c|}
\hline \multirow{2}{*}{$\begin{array}{l}\text { Child } \\
\text { No\# Gender }\end{array}$} & \multirow{2}{*}{$\begin{array}{l}\text { MRT/ } \\
\mathrm{CT}\end{array}$} & \multirow{2}{*}{$\begin{array}{l}\text { Clinical } \\
\text { side }\end{array}$} & \multirow{2}{*}{$\begin{array}{l}\text { Gestation } \\
<34 \\
\text { weeks }\end{array}$} & \multirow{2}{*}{$\begin{array}{l}\text { Gestation } \\
>=34 \\
\text { weeks }\end{array}$} & \multicolumn{4}{|c|}{ Imaging pattern } & \multirow[t]{2}{*}{ Miscellaneous } & \multirow{2}{*}{$\begin{array}{l}\text { Localisation } \\
\text { Extent and details of } \\
\text { brain lesion }\end{array}$} \\
\hline & & & & & Malformation & $\begin{array}{l}\text { White } \\
\text { matter } \\
\text { injury }\end{array}$ & $\begin{array}{l}\text { Grey } \\
\text { matter } \\
\text { injury }\end{array}$ & $\begin{array}{l}\text { Focal vascular } \\
\text { insult }\end{array}$ & & \\
\hline $18 . f$ & MRT & Right & & + & & + & & & & $\begin{array}{l}\text { Left } \\
\text { PVL }\end{array}$ \\
\hline 19.m & $\begin{array}{l}\text { MRT/ } \\
\text { CT }\end{array}$ & Right & & + & & & & $\begin{array}{l}\text { peri-ventricular } \\
\text { hemorraghic } \\
\text { infarction }\end{array}$ & & $\begin{array}{l}\text { Left } \\
\text { Extensive sequelae with } \\
\text { dilatation of the left } \\
\text { lateral ventricle }\end{array}$ \\
\hline 20.m & MRT & Left & & + & + & & & & $\begin{array}{l}\text { Susp lesion of } \\
\text { pyramidal tract }\end{array}$ & $\begin{array}{l}\text { Right } \\
\text { Polymicrogyri in frontal+ } \\
\text { parietal lobes }\end{array}$ \\
\hline 21.m & MRT & Right & & + & & & & & $\begin{array}{l}\text { Left thalamus } \\
\text { smaller }\end{array}$ & $\begin{array}{l}\text { Left hemisphere smaller } \\
\text { Volume loss of central } \\
\text { white matter }\end{array}$ \\
\hline
\end{tabular}

PVL (Periventricular leukomalacia)

MRT (Magnetic Resonance Tomography of the brain)

$C T$ (Computerised Tomography of the brain)

debut of clinical signs and age at diagnosis. Special focus was laid on early handedness, ie impaired hand function on one side, or delayed or abnormal walking [25]. The neurological examination, as in a previous study [1], consisted of assessment of the cranial nerves, head circumference, muscle tone, motor impairment, tendons reflexes, the Babinski response. Speech was evaluated according to Andersen: Zero indicates normal speech, one indistinct speech, two obviously indistinct speech, three severely indistinct speech, and four no speech [26].

The results of computerized tomography (CT)-scans and or magnetic imaging (MRI) of the brain were collected. For describing the brain morphology revealed by brain imaging we used the classification proposed by Reid [15]. The imaging patterns include white matter injury, grey matter injury, focal vascular insults and malformations. Most studies report only the predominant radiologic alteration. In this study we tried to describe the different radiologic abnormalities in each child. All available MRI's and or CT-scans of the brain, were collected and reviewed by the same experienced radiologist.

Epilepsy was diagnosed according to ICD, by the paediatric neurologist at the Karolinska University Hospital, before study comenced. Epilepsy was classified according to the latest criteria of the International league against epilepsy, 2017 [27]. Focal seizures with or without secondary generalization were categorized in the same subtype [7]. Electroencephalogram (EEG) was recorded according to the 10-20 system, $20 \mathrm{~min}^{\prime}$ registration with alert patient. All EEG: $s$ from the study and earlier EEG:s from the case records, were viewed by an experienced neurophysiologist (JP) together with the paediatric neurologist (ET).
All participants were offered a cytomegalovirus DNA assessment in their neonatal screening card.

\section{Results}

\section{Clinical assessment}

The results are summarized in Table 1. Clinical presentation.

Forty-seven children fulfilling the SPCE-criteria of hemiplegia were identified and invited to participate in the study. The majority of the 21 children who consented to participate in the study were boys, fifteen. Only six girls took part in the study. Five children were born preterm, three males and two females. Right-sided hemiplegia was present in fourteen and left-sided in seven children. Only one child was dyskinetic, the others were spastic. Cranial nerves were affected in 14 of the 21 children. Strabismus was found in five, hemianopia, or quadrant defect in four children. Sensory neuronal hearing loss occurred in three children, indistinct speech was observed in two.

Out of the forty-two parents, seventeen had higher educational level. The others had mainly lower educational level. Professions were variable.

\section{Risk factors}

Five children were born preterm, four of them before 34 weeks' gestation. Five children were delivered by caesarean section, one because of prenatally diagnosed hydrocephalus. Parturition was rapid in two children, prolonged in one. Diabetes was present in two mothers. Two children were small for gestational age (SGA) and two were large for gestational age (LGA). Neonatal seizures occurred in two of the children, for one concomitantly with asphyxia. One child, caesarean section, because of prenatally diagnosed hydrocephalus, received a ventriculo-peritoneal shunt in the neonatal period. One child was born preterm and suffered 
postnatal skull trauma, one term child suffered postnatal skull trauma and another underwent postnatal hemisphereektomi. Only five of the sixteen children born at term, had no pre- or perinatal risk factor for cerebral palsy. In all only five of the 21 children (24\%) had no pre-, peri- or postnatal risk factor for cerebral palsy.

\section{Developmental milestones}

Early handedness was present in more than $90 \%$ of the cases, 20 out of 21 children. It was noted from 3 months to 1 year of age in 16 out of 21 children. Abnormal or delayed walking was present in eight children.

\section{Brain imaging findings}

The results are summarized in Table 2. Brain imaging findings and Table 3. Epilepsy and brain imaging.

For twenty of the twenty-one participants a MRI and or CT-scan of the brain was available. Examinations were performed from the neonatal period up to 17 years of age. Four of the twenty children with examinations, were born before 34 weeks' and sixteen at, or after 34 weeks' gestation. Left-sided lesion was present in eleven, right-sided in six and bilateral in three children. Seven children showed white matter injury only, two preterm and five term children, for an example see Fig. 1. Grey matter injury only, was not found in any of the children. The five children with focal vascular insults, all had extensive lesions that affected both white and grey matter, see Fig. 2. Malformation was found in four children. Polymicrogyri, which mainly affects cortex, was present in two of them, for an example see Fig. 3. White- and grey matter combined, was present in four children, two term and two preterm, for an example see Fig. 4. The extent of the lesion varied from slight periventricular leucomalacia (PVL) in child No. seven and No. eight, to loss of most of the left hemisphere in child No. sixteen. Summarized in Table 2, Brain imaging findings and Table 3, Epilepsy and brain imaging.

\section{Epilepsy, neonatal seizures and EEG}

Two of the children, who later developed epilepsy were born preterm. One of them, child No 9 had focal seizures at 1 year of age, after a traffic accident. The other child developed focal seizures, the most common seizure type in this study.

Neonatal seizures occurred in two children. Nine children developed epilepsy. Of these, seven children developed focal seizures and two generalized seizures. Epilepsy

TABLE 3 Epilepsy and Brain Imaging

\begin{tabular}{|c|c|c|}
\hline $\mathrm{Nr}$ & Brain imaging findings & Epilepsy \\
\hline 1 & White Matter Injury (WMI) + Grey matter Injury (GMI) & $\begin{array}{l}\text { neonatal convulsions } \\
\text { focal seizures }\end{array}$ \\
\hline 2 & GMl & - \\
\hline 3 & WMI & - \\
\hline 4 & WMI + GMI focal vascular insult & focal seizures \\
\hline 5 & WMI & - \\
\hline 6 & no examination & - \\
\hline 7 & WMI & - \\
\hline 8 & WMI & - \\
\hline 9 & $\mathrm{WMI}+\mathrm{GMI}$ & focal seizures \\
\hline 10 & WMI + GMI+ focal vascular insult & focal seizures \\
\hline 11 & WMI + GMI+ focal vascular insult & neonatal convulsions \\
\hline 12 & WMI + GMI hemi-megaencephali & generalized epilepsy \\
\hline 13 & WMI+ GMI & focal seizures \\
\hline 14 & WMI & - \\
\hline 15 & WMI+ GMl & focal seizures \\
\hline 16 & WMI + GMl + focal vascular insult & generalized seizures \\
\hline 17 & WMI & - \\
\hline 18 & WMI & - \\
\hline 19 & WMI + GMI focal vascular insult & focal seizures \\
\hline 20 & GMl & - \\
\hline 21 & WMI+ GMI & - \\
\hline
\end{tabular}




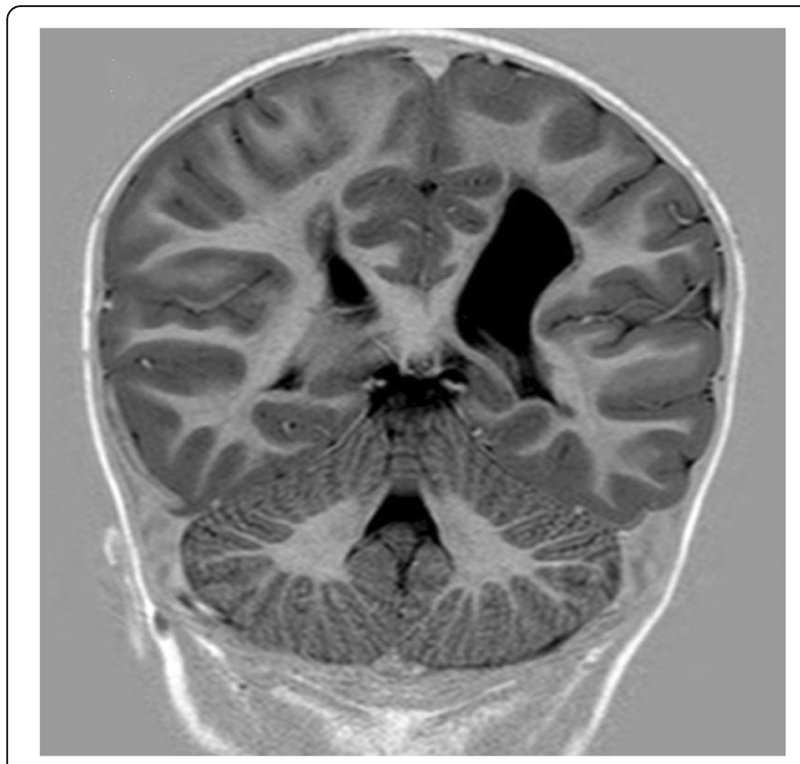

Fig. 1 White matter lesion. Sequelae after periventricular leucomalacia in left parietal lobe, but also in right cerebral hemisphere. Coronal image

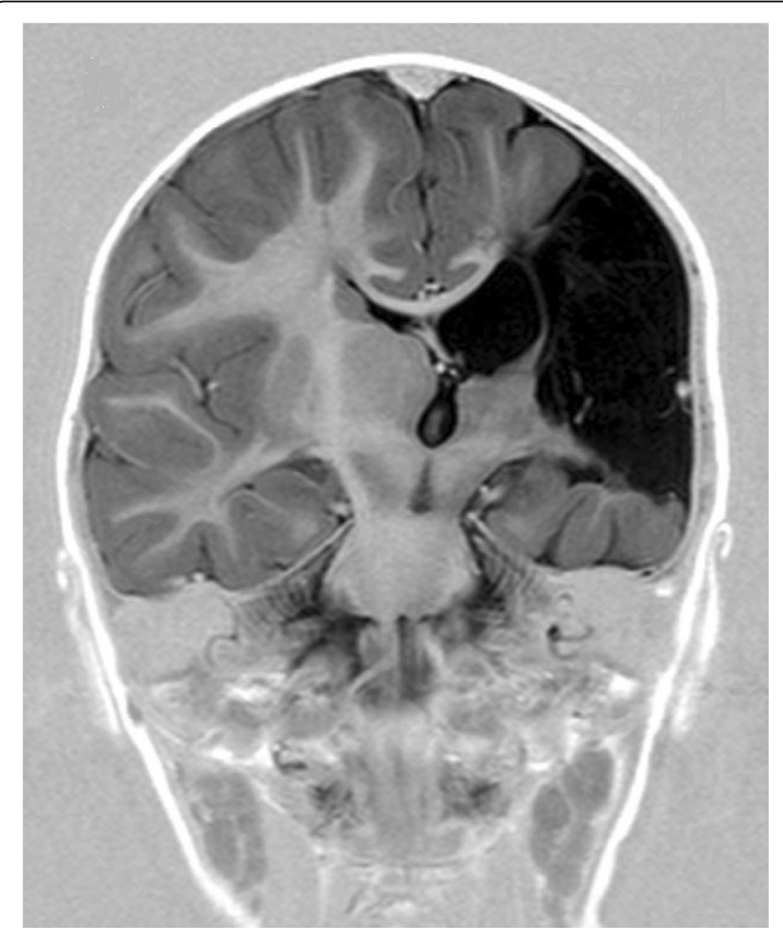

Fig. 2 Sequelae after vascular insult of left middle cerebral artery with major volume loss. Coronal image

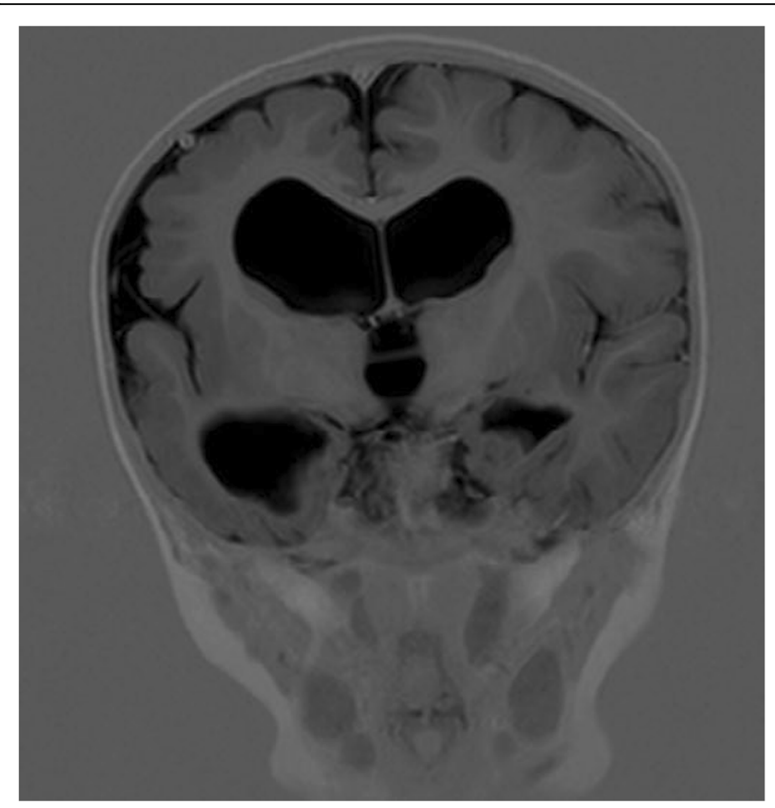

Fig. 3 Cortical malformation, polymicrogyri, in right frontal lobe. In addition dilated ventricles. Coronal image

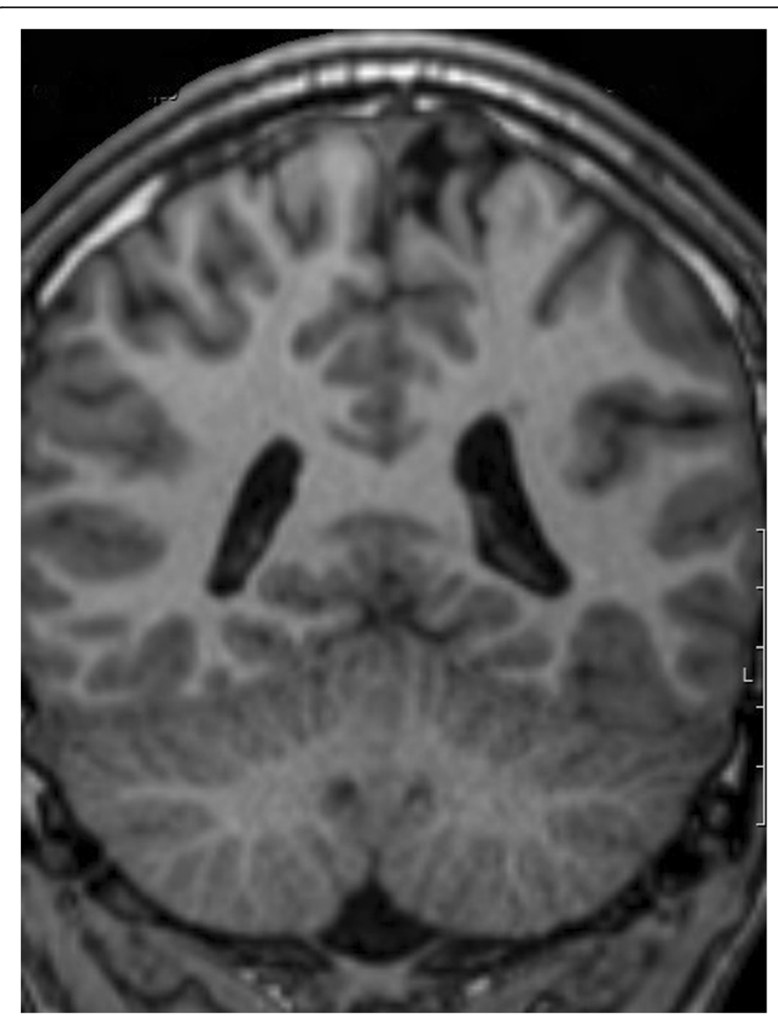

Fig. 4 Combined lesion in white matter and cortex. Coronal image 
Table 4 EEG and epilepsy

\begin{tabular}{|c|c|c|c|c|c|c|c|c|}
\hline Nr. & $\begin{array}{l}\text { Age } \\
\text { at exam }\end{array}$ & Gender & $\begin{array}{l}\text { Motor } \\
\text { impairment }\end{array}$ & EEG findings & Other Events & $\begin{array}{l}\text { Epilepsy } \\
\text { Seizure type } \\
\text { Debut at age }\end{array}$ & Active & $\begin{array}{l}\text { Resolved at age } \\
\text { Seizure free } \\
\text { with AED }\end{array}$ \\
\hline 1 & 14 & Male & Right & $\begin{array}{l}\text { Mild episodic abnormity } \\
\text { maximum left temporally }\end{array}$ & & $\begin{array}{l}\text { neonatal } \\
\text { convulsions } \\
\text { focal seizures } \\
2 \text { years }\end{array}$ & - & $\begin{array}{l}\text { treatment } \\
\text { neonatally to } 6 \\
\text { months } \\
\text { treatment from } \\
2 \text { to } 3 \text { years }\end{array}$ \\
\hline 2 & 8 & Male & Left & $\begin{array}{l}\text { Moderate generalized abnormality left } \\
\text { dominance }\end{array}$ & & - & - & \\
\hline 3 & 11 & Male & Left & Normal EEG & & - & & \\
\hline 4 & 12 & Male & Right & $\begin{array}{l}\text { No study EEG. } \\
\text { Clinical EEG at seizures onset focal left } \\
\text { epileptiform activity }\end{array}$ & & $\begin{array}{l}\text { Focal seizures } \\
12 \text { years }\end{array}$ & + & \\
\hline 5 & 9 & Male & Right & Normal EEG & & - & - & \\
\hline 6 & 12 & Male & Right & mild generalized abnormality & & - & - & \\
\hline 7 & 10 & Female & Right & $\begin{array}{l}\text { Mild, mainly episodic bilateral abnormality right } \\
\text { dominance }\end{array}$ & & - & & \\
\hline 8 & 13 & Female & Right & Normal EEG & & - & - & \\
\hline 9 & 10 & Male & Left & $\begin{array}{l}\text { Focal abnormality temporo-parieto-occipitally } \\
\text { right. Bilateral reduced alpha-activity }\end{array}$ & $\begin{array}{l}\text { Traffic accident at } \\
1 \text { year }\end{array}$ & $\begin{array}{l}\text { Focal seizures } \\
1 \text { year }\end{array}$ & & 5 years \\
\hline 10 & 10 & Female & Right & Normal EEG & & $\begin{array}{l}\text { focal seizures } \\
>12 \text { years } \\
2 \text { years after } \\
\text { study } \\
\text { examination }\end{array}$ & - & \\
\hline 11 & 10 & Male & Right & Normal EEG & & $\begin{array}{l}\text { Short focal } \\
\text { neonatal } \\
\text { convulsions }\end{array}$ & - & \\
\hline 12 & 15 & Female & Left & $\begin{array}{l}\text { Continuous generalized epileptiform discharges } \\
\text { with right dominance }\end{array}$ & $\begin{array}{l}\text { Right-sided } \\
\text { hemispherectomi }\end{array}$ & $\begin{array}{l}\text { generalized } \\
\text { epilepsy } \\
2 \text { months }\end{array}$ & + & $\begin{array}{l}\text { Resistant to } \\
\text { AED }\end{array}$ \\
\hline 13 & 7 & Male & Right & Normal EEG & & $\begin{array}{l}\text { Focal seizures } \\
4 \text { years }\end{array}$ & + & \\
\hline 14 & 14 & Female & Left & Normal EEG & & - & & \\
\hline 15 & 11 & Male & Right & $\begin{array}{l}\text { Mild generalized abnormality with left dominance } \\
\text { with sparse amount of epileptiform discharges } \\
\text { left frontal and medial }\end{array}$ & & $\begin{array}{l}\text { Focal seizures } \\
4 \text { years }\end{array}$ & - & $\begin{array}{l}\text { Seizure free } \\
\text { with AED }\end{array}$ \\
\hline 16 & 9 & Male & Right & $\begin{array}{l}\text { Moderate amount of epileptiform discharges left } \\
\text { hemisphere fronto-centrally and/or fronto- } \\
\text { temporally }\end{array}$ & $\begin{array}{l}\text { Head trauma at } 6 \\
\text { months, epidural } \\
\text { hematoma }\end{array}$ & $\begin{array}{l}\text { Generalized } \\
\text { seizures since } \\
\text { trauma }\end{array}$ & + & $\begin{array}{l}\text { AED therapy } \\
\text { resistant }\end{array}$ \\
\hline 17 & 13 & Male & Left & Normal EEG & & - & & \\
\hline 18 & 9 & Female & Right & $\begin{array}{l}\text { Mild to moderate amount of generalized slow } \\
\text { activity with slight left-sided dominance }\end{array}$ & & - & & \\
\hline 19 & 15 & Male & Right & $\begin{array}{l}\text { Somewhat increased amount of slow activity } \\
\text { over the left hemisphere. No distinct epileptiform } \\
\text { activity. }\end{array}$ & & $\begin{array}{l}\text { Focal seizures } \\
3 \text { years. }\end{array}$ & & $\begin{array}{l}\text { No seizures } \\
\text { since age } 9 \\
\text { years with AED }\end{array}$ \\
\hline 20 & 12 & Male & Left & Normal & & - & & \\
\hline 21 & 12 & Male & Right & Normal & & - & & \\
\hline
\end{tabular}

onset was from one to 12 years of age. Diagnosis was made at the neuropaediatric unit, Karolinska University Hospital. Seizures resolved at three to 12 years of age. Active epilepsy was still present in four children out of nine, two were seizure free with AED. Initial treatment was mostly with Lamotrigin, Hydroxykarbamazepin or
Levetiracetam. Resistance to drug theraphy was found in three Children. Child No. 16 tried ketogen diet, without success. None of the children were identified with epileptic encephalopathy. Focal abnormalities in the EEG were the main findings, as summarized in Table 4, EEG and epilepsy. Ten children had normal EEG: s. 


\section{Brain imaging and epilepsy}

All children who developed neonatal seizures, or later on epilepsy, showed both white and grey matter injury. Patient No. 16 with the most extensive brain lesion, consequently had the most serious seizures: Drug therapy resistant generalized seizures. The others responded to therapy. The grey- and white matter injury in three children, was a part of a focal vascular insult. See Table 3.

CMV- DNA was negative for the eleven children tested.

\section{Discussion}

Less than $50 \%$ of the eligible subjects participated, which may have biased the results. Probably the children with most problems, consented to participate. This may be due to the sparse attention, which is offered in routine health care follow up.

In agreement with many other studies, $70 \%$ of the participants in this study were male [28] .

In Stockholm, Sweden, only children included in the high risk group are considered for special follow up by a neonatologist or neurologist. This high risk group encompasses major perinatal risk factors such as asphyxia, neonatal seizures, cerebral haemorraghe, hypoxic- ischaemic encephalopathy, sepsis etc., leading to care in the neonatal unit. Birth before 28 weeks' gestation and/ or children being small for gestational age are also included in the high risk group [23]. Children without major perinatal risk factors will be examined by a general practitioner at the child health center.

Most patients with cerebral palsy are born at term [4]. In this study, term children comprised $70 \%$. In "A systematic review of risk factors for cerebral palsy in children born at term in developed countries", McIntyre found ten consistent risk factors for cerebral palsy in term children: Placental abnormalities, major and minor birth defects, low birth weight, meconium aspiration, instrumental/ emergency caesarean delivery, birth asphyxia, neonatal seizures, respiratory distress syndrome, hypoglycaemia and neonatal infection. However, other risk factors such as maternal disease or being large for gestational age were not statistically significant. But these risk factors may work together along a causal pathway [10]. Thirteen of the sixteen term children had consistent risk factors for cerebral palsy, according to McIntyre [10]. Three of them had minor risk factors, such as rapid parturition and prolonged labor, see Table 1 clinical presentation. In all only five of the 21 children had no pre-, peri- or postnatal risk factors for cerebral palsy.

Motor impairment as observed by parents was evident at age 1 year or before. However diagnosis, was given only between age one and a half to 6 years! Early handedness was present in $90 \%$ of the cases. In Japan all children can meet a paediatrician for regular care.
Although epilepsy is present in $30-40 \%$ of cases, not many recent studies of epilepsy in cerebral palsy were found $[6,8,9,11,13]$. In this cohort of 21 children, nine (40\%) developed epilepsy. All had both grey and white matter injury. Of these, five had a focal vascular insult, that affected both white and grey matter. In the study published by Reid 2015 the prevalence of epilepsy was highest where there was generalized cortical-subcortical involvement and white matter loss [30]. (In the study by) Legault [31] found epilepsy more frequent in cerebral palsied children with cerebral vascular accident, or deep brain injury. The size of the injury is also important. The seizures of the child, with the most extensive injury, were drug therapy resistant. Very few clinical studies, if any describe EEG, epilepsy in cerebral palsy. Most studies are register based.

\section{Conclusions}

Pre-, peri- or postnatal risk factors for cerebral palsy, present in sixteen out of twenty-one hemiplegic children in this study, are important for early case identification. Parents often observe the child's assymetric hand function during the first year of life. To avoid diagnostic delay, any child with risk factors for cerebral palsy and or impaired hand function, should be offered a check-up by a paediatrician or a paediatric neurologist.

A combined grey- and white matter injury, often as a part of a focal vascular insult, was associated with epilepsy in this cohort. EEG can improve the understanding of epilepsy in cerebral palsy.

\section{Abbreviations \\ CMV: Cytomegalovirus; CP: Cerebral Palsy; CPUP: Swedish national cerebral palsy register; CT: Computerized tomography of the brain; EEG: Electro EncephaloGram; LGA: large for gestational age; MRI: Magnetic resonance imaging of the brain; PCR: Polymerase chain reaction; PVL: Periventricular leukomalacia; SGA: Small for gestational age; SPCE: Surveillance of Cerebral Palsy in Europe}

\section{Acknowledgements}

Thanks to the Norrbacka-Eugenia Foundation for financial support. Thanks to Per Almqvist, Gerald Cooray, None-Marie Kemp and Åsa Skärlen for valuable assistance!

\section{Authors' contributions}

Designed the study: ET and JP. Administrated the clinical study and data collection: ET Data entry: ET. Analysis: ET, JP and BI. Contributed to writing the manuscript and approved the final version: ET, JP BI Literature research, ET. Study supervision JP. All authors read and approved the final manuscript ET JP BI.

\section{Funding}

The Norrbacka Eugenia Foundation for disabled children supported the project by funding research time. The Norrbacka Eugenia Foundation sponsors research projects for children with motor impairment. It has no role in the design of the study or collection, analysis, and interpretation of data or in writing the manuscript. Open access funding provided by Karolinska Institute.

Availability of data and materials

The protocols and dataset generated during the study, will be available to view upon reasonable request by contacting the corresponding author. 


\section{Ethics approval and consent to participate}

The study was approved by the Regional Ethical Review Board in Stockholm. Parents provided written informed consent.

\section{Consent for publication}

Not applicable.

\section{Competing interests}

The authors declare that they have no competing interests.

\section{Author details}

'Department of Clinical Neuroscience, Karolinska Institute, Tomtebodavägen 18 A, 17177 Stockholm, Sweden. 'Läkarhuset Odenplan, Odengatan 69, 113 22 Stockholm, Sweden. ${ }^{3}$ Department of Clinical Neurophysiology, Karolinska University Hospital, Eugeniavägen 11, 17176 Stockholm, Sweden.

Received: 12 March 2019 Accepted: 3 February 2020

Published online: 12 March 2020

\section{References}

1. Tillberg E, Radell U, Amark P. Postnatal cerebral infection leading to hemiplegic cerebral palsy: clinical description of 13 children in Stockholm. Sweden Disabil Rehabil. 2008;30(5):338-47.

2. Rosenbaum $P$, et al. A report: the definition and classification of cerebral palsy April 2006. Dev Med Child Neurol Suppl. 2007;109:8-14.

3. Colver A, Fairhurst C, Pharoah PO. Cerebral palsy. Lancet. 2014;383(9924): 1240-9.

4. Graham HK, et al. Cerebral palsy. Nat Rev Dis Primers. 2016;2:15082.

5. Stanley FB, E, Alberman E. Cerebral palsies: Epidemiology and causal pathways. In: Clinics in developmental medicine no 151. London: Mac Keith press; 2000.

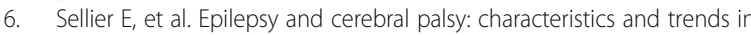
children born in 1976-1998. Eur J Paediatr Neurol. 2012;16(1):48-55.

7. Zelnik N, et al. Risk factors for epilepsy in children with cerebral palsy. Eur J Paediatr Neurol. 2010;14(1):67-72

8. Pisani $F$, et al. Incidence of neonatal seizures, perinatal risk factors for epilepsy and mortality after neonatal seizures in the province of Parma. Italy Epilepsia. 2018;59(9):1764-73.

9. Glass HC, et al. Outcomes after acute symptomatic seizures in children admitted to a neonatal Neurocritical care senvice. Pediatr Neurol. 2018;84:39-45.

10. Mclntyre S, et al. A systematic review of risk factors for cerebral palsy in children born at term in developed countries. Dev Med Child Neurol. 2013; 55(6):499-508

11. El-Tallawy HN, et al. Epileptic and cognitive changes in children with cerebral palsy: an Egyptian study. Neuropsychiatr Dis Treat. 2014;10:971-5.

12. Singhi $P$, et al. Epilepsy in children with cerebral palsy. J Child Neurol. 2003; 18(3):174-9.

13. Cooper MS, et al. Seizures in Children With Cerebral Palsy and White Matter Injury. Pediatrics. 2017;139(3):1-9.

14. Gururaj AK, et al. Epilepsy in children with cerebral palsy. Seizure. 2003;12(2): $110-4$

15. Reid SM, et al. Population-based studies of brain imaging patterns in cerebral palsy. Dev Med Child Neurol. 2014;56(3):222-32.

16. Ahlin $\mathrm{K}$, et al. Antecedents and neuroimaging patterns in cerebral palsy with epilepsy and cognitive impairment: a population-based study in children born at term. Acta Obstet Gynecol Scand. 2017;96(7):828-36.

17. Delacy, M.J., S.M. Reid, and G. Australian Cerebral Palsy Register, Profile of associated impairments at age 5 years in Australia by cerebral palsy subtype and Gross Motor Function Classification System level for birth years 1996 to 2005. Dev Med Child Neurol, 2016. 58 Suppl 2: p. 50-56.

18. Cans C, et al. Surveillance of cerebral palsy in Europe: a collaboration of cerebral palsy surveys and registers. Dev Med Child Neurol. 2000;42(12):816-24.

19. Woolfenden $\mathrm{S}$, et al. Impact of social disadvantage on cerebral palsy severity. Dev Med Child Neurol. 2018

20. Forthun I, et al. Parental socioeconomic status and risk of cerebral palsy in the child: evidence from two Nordic population-based cohorts. Int $J$ Epidemiol. 2018

21. Himmelmann $\mathrm{K}$, et al. Risk factors for cerebral palsy in children born at term Acta Obstet Gynecol Scand. 2011;90(10):1070-81.
22. Hjern A, Thorngren-Jerneck K. Perinatal complications and socio-economic differences in cerebral palsy in Sweden - a national cohort study. BMC Pediatr. 2008;8:49

23. Guidelines Swedish Neonatal Society 2015.

24. Smithers-Sheedy $\mathrm{H}$, et al. Congenital Cytomegalovirus among children with cerebral palsy. J Pediatr. 2017;181:267-71 e1.

25. Uvebrant P. Clinical presentation and neurology. In: Congenital hemiplegia. Clinics in Development Medicine No. 150: 53-64. London: Mac Keith press; 2000.

26. Andersen GL, et al. Cerebral palsy in Norway: prevalence, subtypes and severity. Eur J Paediatr Neurol. 2008;12(1):4-13.

27. Berg AT, et al. Revised terminology and concepts for organization of seizures and epilepsies; report of the ILAE Commission on Classification and Terminology, 2005-2009. Epilepsia. 2010;51(4):676-85.

28. Himmelmann $K$, Uvebrant $P$. The panorama of cerebral palsy in Sweden part XII shows that patterns changed in the birth years 2007-2010. Acta Paediatr. 2018;107(3):462-8.

29. Japan Healthcare Info. Child health and Childcare. http://japanhealthinfo com/child-health-and-childcare/pediatrics.

30. Reid SM, et al. Grey matter injury patterns in cerebral palsy: associations between sturtural involvement on MRI and clinical outcomes. Dev Med Child Neurol. 2015:57:1159-67.

31. Legaut $G$, Shevell M. Predicting comorbidities with neuroimaging in children with cererbral palsy. Pediatr Neurol. 2011:45:229-32.

\section{Publisher's Note}

Springer Nature remains neutral with regard to jurisdictional claims in published maps and institutional affiliations.
Ready to submit your research? Choose BMC and benefit from:

- fast, convenient online submission

- thorough peer review by experienced researchers in your field

- rapid publication on acceptance

- support for research data, including large and complex data types

- gold Open Access which fosters wider collaboration and increased citations

- maximum visibility for your research: over $100 \mathrm{M}$ website views per year

At BMC, research is always in progress.

Learn more biomedcentral.com/submissions 